\title{
Rendering the Divine Name in Romans 10:13
}

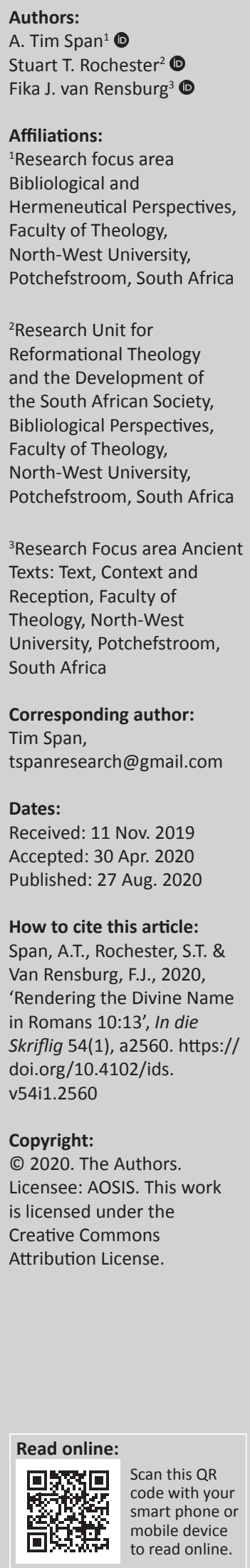

The Tetragrammaton has great significance in Judaism and Christianity. Hebraist George Howard has proposed a theory of New Testament documentary origins. On the basis of early Septuagint/Old Greek (LXX/OG) manuscript findings, Howard has suggested that the Tetragrammaton has played a part in the transmission history of the New Testament. The New Testament writers, according to Howard, would have retained the Tetragrammaton in their Old Testament citations. With the success of the Gentile mission, uninformed copyists replaced the Tetragrammaton with the Greek word кúpıs [Lord]. The result was that passages that applied only to YHWH were now applied in error to both the Lord God and the Lord Jesus Christ so that the high Christology of the New Testament was, in part, artificially elevated through scribal corruption. A detailed response is in order to evaluate the validity of Howard's thesis. As a test case, the LXX/OG quotation from Joel 2:32 (3:5) in Romans 10:13 is examined to determine the proper referent of the linked word Lord. Contextual and grammatical indicators point to Jesus as the 'Lord' in the passage. Combined with documentary evidence, the Tetragrammaton thesis fails to convince. The final section of research applies the findings to two Divine Name Bibles, and the suitability of the Tetragrammaton in anglicised or Hebrew characters, as a translation option, is evaluated.

Keywords: Romans 10:13; Joel 2:32 (3:5); George Howard; Divine Name; Tetragrammaton; Yahweh, Jehovah; Lord; kúpış, kurios, kyrios; New World Translation (NWT); Institute for Scripture Research.

\section{Introduction}

In 1977, George Howard published a theory which has exerted some influence in the areas of New Testament and Septuagint (LXX) studies (e.g. Howard 1992c; Trobisch 2000). ${ }^{1}$ Howard argues that the text of the New Testament has experienced a systematic scribal corruption with far-reaching textual and Christological implications. According to Howard, the writers of the New Testament regularly used the Tetragrammaton in their quotations of the Old Testament. The discovery of a few early LXX/OG manuscripts containing the Tetragrammaton in Hebrew characters or Greek transliteration forms the basis of his argument. ${ }^{2}$ According to Howard, the New Testament writers would have used these types of manuscripts and would likely have retained the Divine Name in their Old Testament citations. With the progress of the Gentile mission, Christian scribes, unfamiliar with the significance of the Tetragrammaton, rendered the Divine Name with the surrogate kópış and sometimes $\theta \varepsilon$ ćs. The resultant situation was that now both Lord God and Lord Jesus Christ shared the title kúpıs [Lord] and in many situations were no longer easily distinguished. The ramifications for Howard are clear: the high Christology of the New Testament was due more to the scribal convention of the first and second centuries than to the original New Testament writings. Even the Christological controversies of the following centuries may have looked quite different if the Tetragrammaton had been used exclusively of the $\mathrm{God}^{3}$ of Israel and not of Jesus Christ. Romans 10:13 provides a good test case for evaluating Howard's theory.

\section{Romans 10:13 in grammatical-historical context}

In Romans 10:13, Paul quotes from Joel 2:32 (3:5 in Hebrew) in his treatment of Israel and the gospel. The quotation is the same as that found in Acts 2:21: 'everyone who calls on the

1.The Anchor Bible Dictionary (ABD) (Freedman, Herion, Graf et al. 1992) has included the article from Howard (1992c) entitled, 'Tetragrammaton in the New Testament'. This might suggest that Howard's New Testament Tetragrammaton theory has widespread currency among New Testament scholars. There is no such consensus in the New Testament community. Most reviews of Howard's thesis are cursory (e.g. Hurtado 2003:182ff). This provides incentive to evaluate Howard's thesis in detail and within a defined scope (see footnote 4 below).

2.Howard examines the following manuscripts: P. Rylands Gk. 458, P. Fouad Inv. 266, 8HevXIIgr, and pap4QLXXLev ${ }^{\text {b }}$. A fuller examination of these manuscripts and the textual traditions that informed the New Testament can be found in Span (2018).

3.Although Jesus is referred to as God in places in the New Testament, it is exceptional usage, and the customary referent of the term God ([i்] $\theta \varepsilon$ ć) is the Father (Harris 1992:42) who is referred to variously in this article: God, God of Israel, Lord God, and YHWH. The Christological significance of the exceptional use of (ó) $\theta$ cós in relation to Jesus Christ is a related issue, but largely outside the scope of this study. 


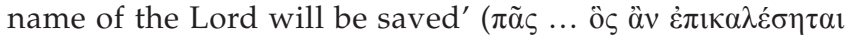

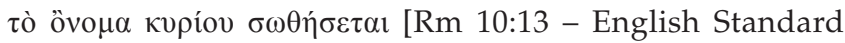
Version (ESV); Novum Testamentum Graece, 28th ed. (NA28)]). Since this LXX/OG quotation includes a reference to the Tetragrammaton in the Hebrew Vorlage, Howard (1977) ${ }^{4}$ would have us consider that the Divine Name was likely in the earliest LXX/OG manuscripts which presumably Paul used and, as such, he would have retained the Divine Name in his citation of Joel 2:32 (3:5). According to Howard's proposal (1977), יהוה in some form would have been found in the place where кupíov appears in our Greek text. If the Divine Name is the authentic reading here, the referent is not Jesus Christ, but YHWH. The implication for exegesis is obvious: Jesus is not referred to in this citation and any honour received from the passage belongs rightfully to the Father and not to Jesus.

In response to this, my task is twofold: First, to determine which reading has the greatest claim to authenticity; and second, to enquire about the Christological implications of this determination. On the basis of the conclusions reached, the last part of the study will examine two Divine Name Bibles and evaluate the suitability of using the Tetragrammaton in Romans 10:13.

\section{The reading with the greatest claim to authenticity}

The manuscripts of the letter to the Romans are unanimous in support of the authenticity of кvpíov in Romans 10:13. There is no manuscript support for the Tetragrammaton here. Howard (1977) knows this, but would add that when the Tetragrammaton in the Greek manuscripts of the New Testament fell into the hands of 2nd-century scribes who had no knowledge of the Tetragrammaton, kúpıs was substituted instead. Now passages such as Romans 10:13, through the кúpros substitution, are not necessarily appropriate only to the Lord God, but may refer to the Lord Christ. The implications for Christology would be that the honours properly belonging to $\mathrm{YHWH}$ are now mistakenly applied to Jesus through the kúpros exchange.

A detailed examination of the immediate context and the internal constraints of the passage will determine the identity of the 'Lord' in Romans 10:13 and the suitability of each reading.

Romans 10:13 is situated in the wider section of Romans 9-11, dealing with Israel and the salvation that comes through the gospel of Christ. Paul contrasts the righteousness that is through the works of the law with the righteousness that comes by faith. Paul raises the question:

4. Howard (1977) presents his theory with global application to the documentary origins of the New Testament. It is this wide application that make the discussion of the citation of Joel 2:32 (3:5) in Romans 10:13 relevan. The suitablity of the of the citation of Joel 2.32 (3.5) in Romans 10.13 relevant. The suitability of the general application in a specific passage, directly addresses the scope and validity of the Tetragrammaton thesis.
What shall we say, then? That Gentiles who did not pursue righteousness have attained it, that is, a righteousness that is by faith; but that Israel who pursued a law that would lead to righteousness did not succeed in reaching that law. (Rm 9:30-31 - ESV)

Paul then answers his own question about Israel's failure: 'Why? Because they did not pursue it by faith, but as if it were based on works' (Rm 9:32 - ESV). In a composite quotation from Isaiah $(28: 16 ; 8: 14)$, Paul locates the heart of the problem for the Jews: 'Behold, I am laying in Zion a stone of stumbling, and a rock of offense; and whoever believes in him will not be put to shame'

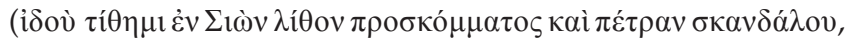

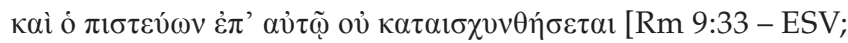
NA28]).

\section{Jesus Christ, the stumbling stone}

What or who is this 'stumbling stone'? ( $\tau \tilde{\omega} \quad \lambda i \theta \omega$ $\tau$ ov

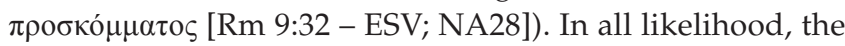
stumbling stone is Jesus Christ. Paul uses similar language in 1 Corinthians 1:23 in referring to Christ: '... we preach

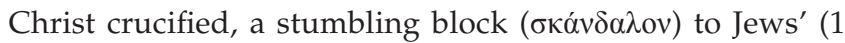
Cor 1:23 - ESV; NA28). The concept stumbling block ( $\sigma \kappa \alpha ́ v \delta \alpha \lambda o v$ ) is reminiscent of the concept used in the composite quotation in Romans 9:33: rock of offense ( $\pi \dot{\varepsilon} \tau \rho \alpha v$ $\sigma \kappa \alpha v \delta \alpha ́ \lambda o v)$. This idea of Christ as a 'stumbling stone' is found also in other New Testament writings. In 1 Peter 2:6-8, Christ is referred to as the 'cornerstone' for believers, integral to the 'spiritual house' (2:5) God is building, but for unbelievers he is an obstacle: 'a stone of stumbling, and a

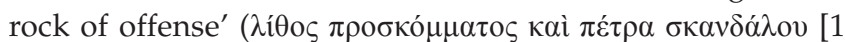
Pt 2:8 - ESV; NA28]). The passage in Peter uses both Isaiah passages (Is 28:16; 8:14) with the addition of Psalm 118:22 for further explanation of the dual role of the cornerstone. Jesus Christ was rejected by his own people, but was accepted by those who put their trust in him: he is both the 'cornerstone' and the 'stumbling stone'. Further confirmation for identifying Jesus as the 'stumbling stone' is found later in the same context of our passage in Romans (10:11): 'Everyone who believes in him will not be put to

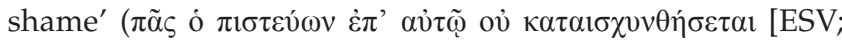
NA28]). This is the second half of the Isaiah citation quoted in Romans 9:33, and the exegesis below will confirm that the referent here is also Christ (Capes 1994:123-124, whole paragraph).

The Christological import of referring to Christ as a 'stumbling stone' is evident when looking at the wider context of Isaiah 8:14, the second of the merged passages in Romans 9:33. In Isaiah 8:14, the stone imagery is used of YHWH:

And he will become a sanctuary and a stone of offense and a rock of stumbling to both houses of Israel, a trap and a snare to the inhabitants of Jerusalem. (Is 8:14 - ESV)

The LXX rendering brings out the contrast between the two uses of the stone: 
And if you trust in him, he will become a sanctuary for you, and you will not encounter him as an obstacle of stone ( $\lambda i \theta$ ov $\pi \rho \circ \sigma \kappa o ́ \mu \mu \alpha \tau)$ ) or like a fall from a rock. But the houses of Jacob are in a snare, and those who sit in Jerusalem are in a pit. (Is 8:14 - Lexham English LXX; Göttingen LXX)

If Paul intersects YHWH and Jesus in the 'stumbling stone' of Isaiah 8:14, the implications for Paul's Christology are clear: 'At the level of exegesis [Paul] brings Christ into intimate relation to $\mathrm{YHWH}$ and posits Christ in an eschatological role which scripture reserves for God' (Capes 1994:124). Romans 9:30-33 is a preface to the larger unit which includes Romans 10:13, and the association of Christ with $\mathrm{YHWH}$ in the Isaiah citation is a contextual consideration in determining the referent of Romans 10:13 and the Christological significance of that conclusion.

\section{Jesus Christ and salvation}

The section in Romans 10:1-13 is a unit with bookends on the subject of 'salvation'. Paul's desire for his fellow countrymen is for their 'salvation' ( $\sigma \omega \tau \eta \rho i ́ \alpha v$ [Rm 10:1 - NA28]). At the other end of the section, Paul concludes with his quote from Joel 2:32 (3:5): 'everyone who calls on the name of the Lord

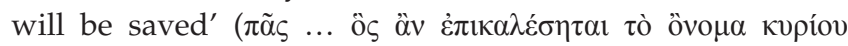
$\sigma \omega \theta \eta \dot{\sigma \varepsilon \tau \alpha \iota ~[R m ~ 10: 13 ~-~ E S V ; ~ N A 28]) . ~ T h i s ~ e m p h a s i s ~ o n ~}$ salvation is picked up in Romans 10:9: 'if you confess with your mouth that Jesus is Lord and believe in your heart that God raised him from the dead, you will be saved' ( $\sigma \omega \theta \eta \dot{ } \sigma \eta$ [ESV; NA28]). Again in the next verse (Rm 10:10), salvation is the common element: 'for with the heart a person believes, resulting in righteousness, and with the mouth he confesses, resulting in salvation' ( $\sigma \omega \tau \eta \rho i ́ \alpha v-N e w$ American Standard Bible [NASV]; NA28). Salvation is the thread that weaves through this section and finds its climax in the quote from Joel 2:32 (3:5).

Paul continues to contrast law-righteousness and faith-righteousness; the latter is from God, the former is not. God's righteousness is found in Christ and is appropriated by faith. In Romans 10:4, Paul makes a startling claim: 'For Christ is the end of the law for

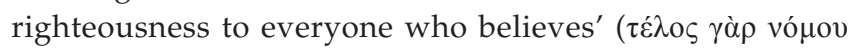

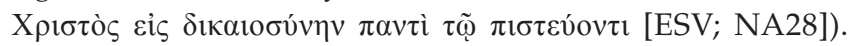
Much ink has been spilled on the subject of Christ as the $\tau \varepsilon \dot{\lambda}$ os of the law, whether this means 'termination, cessation' or 'goal, outcome' (cf. Bauer, Danker, Arndt \& Gingrich 2000 [BDAG], s.v. $\tau \varepsilon \dot{\lambda} \lambda \mathrm{o} \varsigma$ ). Regardless of how one proceeds on this question, the main point in this context is that Christ is the object of belief, and faith in him with its imparted righteousness is the central focus of Paul's exposition in the coming verses. Paul contrasts the righteousness that comes from the law (Lv 18:5) with the righteousness that is by faith, by means of a reworking of Deuteronomy 30:13 and 14. The conclusion is that the nearness of the 'word' in Christ has been available foremost to the Jews. The passages in Deuteronomy 30:13, 14 originally applied to the commandment of the law, but Paul now uses them in relation to Christ.
No heroic feats are required to secure the righteousness that comes through faith in Jesus Christ: "The word is near you, in your mouth and in your heart" (that is, the word of faith that we proclaim)' (Rm 10:8 - ESV). Jesus, the 'stumbling stone', is the object of saving faith, and the Jews are derelict in their unbelief. The righteousness that is based on the law is rooted in human effort, and this has never been the equal of faith in God's plan of salvation in the Old and New Testaments.

Paul continues his exposition of the nearness of the word of faith, which is the gospel message that has been preached by the Early Church. The heart of what is involved in receiving the gospel is summarised in Romans 10:9: 'because, if you confess with your mouth that Jesus is Lord and believe in your heart that God raised him from the dead, you will be

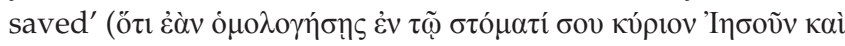

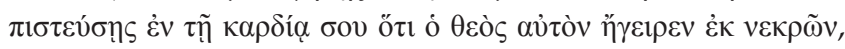
$\sigma \omega \theta \eta ் \sigma n$ [ESV; NA28]). Here Paul is explaining how the word of faith is accessible to the listener. In this way, the ö $\tau$ is taken as causal ('because') in describing how the gospel is 'near' - involving a basic and effectual response. In contrast to this, the New International Version (NIV) and NASV translate the conjunction with 'that'. The passage in Romans $10: 9$ is viewed thus as the content of the 'word of faith'. It is probably better to translate the ö $\tau$ as causal to avoid having two content clauses in a row: 'that is, the word of faith which we are preaching, that if you confess with your mouth ...' (NASV; Moo 1996:657). Nevertheless, the results are nearly the same, emphasising what is involved in receiving the available 'word of faith'.

\section{Jesus is Lord}

At the heart of the early preaching and its response in personal

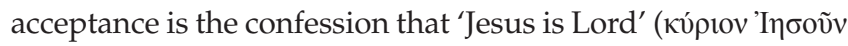
[Rm 10:9 - ESV; NA28]). In Greek Paul makes use of a double accusative (see Blass \& Debrunner 1961 \$157.2 [BDF]; cf. Wallace 1996:187-188 [GGBB]) to encapsulate the content of this 'word of faith'. In 2 Corinthians 4:5, Paul also uses a double accusative in reference to the Lordship of Christ: 'For what we proclaim is not ourselves, but Jesus Christ as Lord

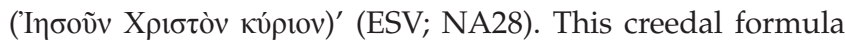
with its Sitz im Leben in the earliest ministry of the church is foundational to all other Christian statements. In 1 Corinthians 12:3 we have seen the seriousness of this confession and the role of the Holy Spirit in its declaration:

Therefore I want you to understand that no one speaking in the Spirit of God ever says 'Jesus is accursed!' and no one can say 'Jesus is Lord' (Kúpıos 'Inбoṽs) except in the Holy Spirit. (1 Cor 12:3 - ESV; NA28)

In Philippians 2:11, a longer form of this confession is used: 'every tongue confess that Jesus Christ is Lord' (ESV). In Codex Vaticanus (B), the creedal nature of the confession in Romans 10:9 is made more explicit with its reading:

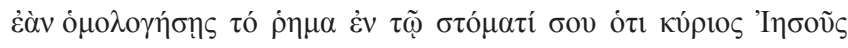
('if you confess with your mouth the word "Jesus is Lord"' [Strazicich 2007:316]). This reading more explicitly defines 


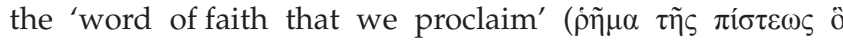

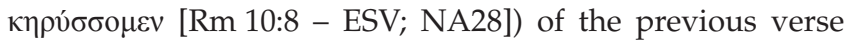
with the basic gospel message that 'Jesus is Lord'. Jesus as Lord is a basic idea that has its roots in the earliest Christian confession. Certainly, there is no doubt that the confession 'Jesus is Lord' is at the heart of the gospel message and constitutes the most basic affirmation of faith. This verse is central in answering the question of who is the referent in the quote from Joel 2:32 (3:5) in Romans 10:13, and as we progress toward that verse, it will become increasingly apparent.

The confession 'Jesus is Lord' is a key distinctive of the faith and practice of earliest Christianity. Dunn (1988:607) identifies the confession 'Jesus is Lord' as a 'slogan of identification' functioning much like the Shema in Judaism: 'as he who says the Shema identifies himself as belonging to Israel, so he who says kúpıov 'Inбoṽv identifies himself as belonging to Jesus'. In 1 Corinthians 8:6, Jesus as the 'one Lord' redefines the Shema and the Divine identity. The idea and confession of Jesus as Lord has permeated every facet of Christian practice from conversion (Ac 2:21; Rm 10:9) to eschatological expectation (1 Cor 16:22). This distinctive statement becomes a core confession in baptism (Ac 2:38 and context), worship (1 Cor 12:3), evangelism (2 Cor 4:5) and exhortation (Col 2:6) (Dunn 1988:607). Faith in Jesus Christ as Lord is coupled with belief in the historicity and efficacy of the resurrection. Peter's speech in Acts 2 also weaves together Jesus' Lordship, resurrection and exaltation. The outcome for the believer is eschatological salvation.

\section{Five yóp statements}

What follows in the next verses is a series of statements each introduced with an explanatory $\gamma \alpha \dot{\alpha} \rho$ [for]. There is an increasing momentum to the passage, and Rowe (2000, [ $\gamma \alpha$ ó added]) aptly describes the effect:

The use of $\gamma \alpha \dot{\alpha} \rho$ five times within 10:10-13 not only connects the phrases to each other, but also gives the reader a sense of being pulled or drawn toward some expected end, with the subsequent phrase each time motivating the preceding phrase:

for ( $\gamma \alpha \dot{\alpha})$ in the heart it is believed ...

for ( $\gamma \alpha \dot{\alpha})$ the Scripture says ...

for ( $\gamma \alpha \dot{\rho} \rho)$ there is no distinction ...

for ( $\gamma \alpha \dot{\rho} \rho)$ the same Lord is Lord of all ...

for ( $\gamma \alpha \dot{\alpha} \rho)$ all who call on the name of the Lord shall be saved. (p. 141)

Romans 10:13 is the climax of the section from 9:30 to 10:13, and the connected statements all have some (accumulating) bearing on deciding the referent of 'Lord' (кирíov) in verse 13 and any significance that can be drawn from this assignment. I will examine each statement in order to determine the cumulative contextual effect on the Joel 2:32 (3:5) quotation.

The first $\gamma \alpha$ o statement in Romans 10:10 points to an explanation of the verbs used in the previous verse: 'for with the heart a person believes, resulting in righteousness, and with the

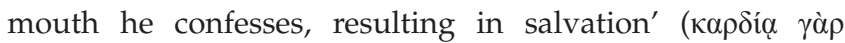

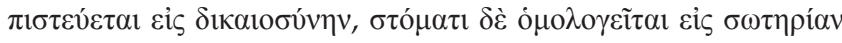
[Rm 10:10 - NASV; NA28]). The order of the verbs is reversed to form a chiasm with 10:9 (Table 1). This accounts for the verbs' reversal and tightly weaves the argument back to the Deuteronomy 30:14 quotation in Romans 10:8: 'The word is near you, in your mouth and in your heart' (ESV). Romans 10:10 forms a transition to verses 11-13, stating in a general way what is universalised in the coming three verses (Moo 1996:658).

The quotation from Isaiah 28:16 in Romans 10:11 is introduced by the second of the five $\gamma \dot{\alpha} \rho$ statements. If Jesus is the referent of the Isaiah 28:16 citation in Romans 9:33, it is likely that he is also the referent here. Further evidence is needed to avoid circular reasoning. To be sure, the quotations in Romans 9:33 and 10:11 do not mention Jesus, but the pronoun used ( $\dot{\varepsilon} \pi$ '

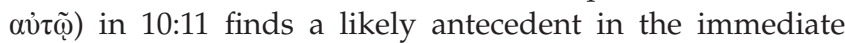
context. In Romans 10:9, the text states that 'God raised him

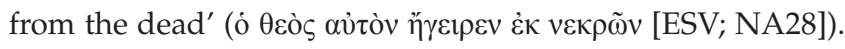
Certainly, the pronoun in 10:9 points to Jesus in the same sentence as its antecedent. Thus, the pronouns in 10:9 and 10:11 continue the author's focus on Jesus. In Romans 10:910, Paul defines the content of the 'word of faith', and now in verse 11, he brings the scriptural proof. This ties the passage from Romans 9:33 with what follows and continues the emphasis on salvation that runs through this passage. I agree with Cranfield $(1979,2: 531)$ that ov $\kappa \alpha \tau \alpha 1 \sigma \chi v v \theta \eta \dot{\sigma \varepsilon \varepsilon \tau \alpha 1}$ ('will not be put to shame' [NA28; ESV]) is the equivalent of $\delta 1 \kappa \alpha 1 \sigma \sigma v ́ v \eta v / \sigma \omega \tau \eta \rho i \alpha v$ [righteousness/salvation]. Immediately after Paul's first quote from Isaiah 28:16, he follows with his heartfelt desire for his countrymen: 'Brethren, my heart's desire and my prayer to God for them is for their

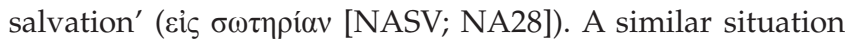
occurs in Romans 10:11. Paul has just spoken of 'salvation', and the quote from Isaiah 28:16 follows again directly on its heels, followed by the salvific overtones of Jesus richly blessing those who call on him. Paul picks up the salvation theme repeatedly in Romans 10, and it is likely that ou

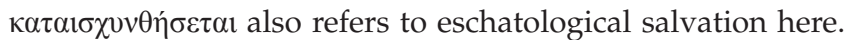
As will be argued below, the verses that ensue only confirm that conclusion.

In conjunction with the salvation theme that runs through Romans 9:30-10:13, there is a continued widening of effect that Paul achieves with his addition of $\pi \tilde{\alpha} \varsigma$ to the quote from Isaiah 28:16, together with other all-encompassing statements. In Romans 10:4, Paul includes everyone in the offer of salvation: 'For Christ is the end of the law for righteousness

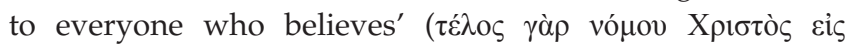

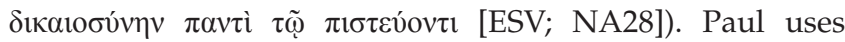
inclusive statements about the breadth of salvation right from his programmatic start in Romans 1:16: 'For I am not

TABLE 1: Chiasm Romans 10:9-10

\begin{tabular}{|c|c|c|}
\hline Segment & Greek & English \\
\hline A & 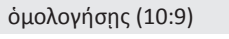 & confess: mouth \\
\hline B & 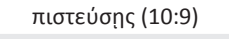 & believe: heart \\
\hline$B^{\prime}$ & 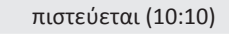 & believe: heart \\
\hline$A^{\prime}$ & 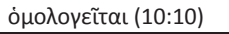 & confess: mouth \\
\hline
\end{tabular}


ashamed of the gospel, for it is the power of God for salvation

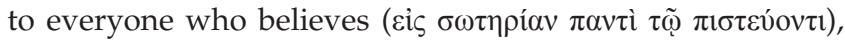
to the Jew first and also to the Greek' (ESV; NA28). Paul's generalised statement in Romans 10:10 continues to emphasise the wide scope of salvation's recipients: 'for with the heart one believes ( $\pi 1 \sigma \tau \varepsilon v i \varepsilon \tau \alpha)$, resulting in righteousness,

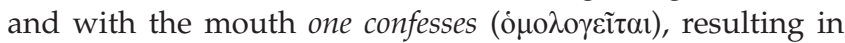
salvation' (based on NASV; NA28, [author's own italics]). Paul continues what he started in Romans 1:16 ( $\pi \alpha v \tau i$ ) and 10:4 ( $\pi \alpha v \tau i)$, and he continues this widening of the scope of salvation with the same word in verses $11(\pi \tilde{\alpha} \varsigma), 12$ ( $\pi \dot{\alpha} v \tau \omega v$,

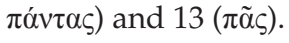

The third and fourth of the five $\gamma \alpha$ s statements draw us that much further toward the author's conclusion in Romans 10:13. In Romans 10:12, Paul brings together the two objectives of his rhetorical argument: 'For there is no distinction between Jew and Greek; for the same Lord is Lord of all, bestowing his riches on all who call on him' (ov̉ yó $\rho$

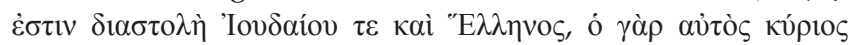

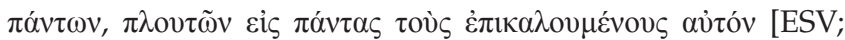
NA28]). Here Paul binds the universality of the gospel with the universal Lordship of Jesus.

Paul picks up the topic of the universality of salvation as a solution to universal sinfulness: 'For there is no distinction ( $\delta 1 \alpha \sigma \tau 0 \lambda \eta)$ : for all have sinned and fall short of the glory of God' (Rm 3:22 - ESV; NA28). Just as there is no 'distinction' in that both Jew and Gentile are under the curse of sin, so all who believe are joined without 'distinction' under the same Lord who mediates God's salvation. From the beginning of Romans, Paul includes both Jews and Gentiles in the scope of salvation. Already in his thesis statement in Romans 1:16, Paul makes it clear that the gospel has universal application.

The fourth róp, in tying together the two themes of the universality of the gospel and the Lordship of Jesus, prepares the reader for the rhetorical conclusion in 10:13. There can be little doubt that the kv́pıs in 10:12b refers to

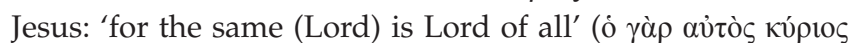
$\pi \alpha ́ v \tau \omega v$ [ESV; NA28]). This instance of kúptoৎ follows next

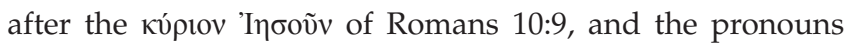
used in the preceding verses have their proper antecedent in the person of Jesus. The 'same (Lord)' can only be the 'Lord' of the immediate context. The Lordship of Jesus has universal breadth that spans all people, and the soteriological ramifications are clear: one Lord, one people, one method of salvation. Rowe (2000) draws the necessary connections in his theological assessment:

$[I] \mathrm{t}$ is because the Jews and Greeks have the same Lord that there is no distinction between them. That is, because there is one Lord (cf. 1 Cor 8:6), there is one human community $(\pi \tilde{\alpha} \varsigma)$. The theological universality $(12 b)$ is the ground of the anthropological universality (12a). (pp. 147-148)

The supreme claim that Jesus is 'Lord of all' is something that Jews would have used without reservation only in reference to the God of Israel - the bold usage here has significant Christological implications. In Acts 10:36 Jesus is also referred to as 'Lord of all' (oṽ [ESV; NA28]). Dunn (1988:610) suggests that Paul may be using a Christian formula that had its roots in Hellenistic Jewish usage. In Job 5:8 (LXX) similar words are used of the Lord God: 'But rather I will implore the Lord, and I

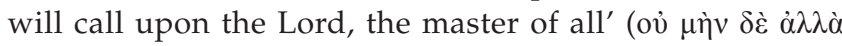

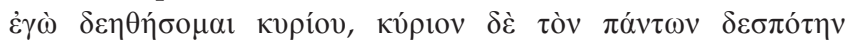
$\dot{\varepsilon} \pi \iota \kappa \alpha \lambda \varepsilon ́ \sigma o \mu \alpha \iota$ [Lexham English LXX; Göttingen LXX]). In bringing Jews and Gentiles under the one Lord, Paul echoes the language he used in Romans 3:29-30 where he unites Jews and Gentiles under the one God (cf. Eph 4:5, 6). The referents are different, but the ideas are decidedly similar as Dunn (1988:617) explains: 'Paul seems deliberately to merge the role of Jesus as Lord with that of God himself.' In Romans, Paul does not use the Christological title of 'God' $(\theta \varepsilon$ ó $\varsigma$ ) in reference to Jesus, except in Romans 9:5, but as is evident here and in the following clauses, the salvific purposes and exalted language bring the One Lord (Jesus) and the One God (of Israel) into deliberate equation (cf. 1 Cor 8:6).

The language of referring to Jesus as the 'same (Lord)' is also found in 1 Corinthians 12:4-6 in connection with the Father, Son and Holy Spirit:

Now there are varieties of gifts, but the same Spirit; and there are

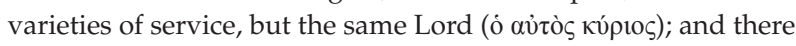
are varieties of activities, but it is the same God who empowers them all in everyone. (ESV; NA28)

The plurality of different people like different ministries is subsumed under the Lordship of the One Lord.

In this context in Romans 10, the riches that Jesus bestows are likely the benefits of salvation. The context constrains the range of possible options for the statement: 'bestowing

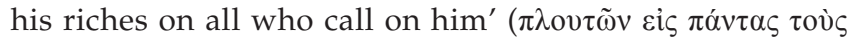

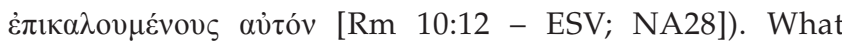
precedes and what follows make it clear that Jesus' riches are bound up with eschatological salvation. Universal salvation through the One Lord is what Paul brings to this context in the preceding verses, and the text in the following verse only secures this understanding: 'For "everyone who calls on the name of the Lord will be saved"' (Rm 10:13 - ESV).

Paul often uses the language of wealth to convey the abundant resources of God and of Christ (e.g. Rm 2:4; 9:23; 11:33; 1 Cor 1:5; 2 Cor 8:9; Eph 1:7; 2:7; 3:8,16; Phlp 4:19; Col 1:27; Moo 1996:660, footnote 71, 72). In Romans 2:4, it is the riches of God's unmerited kindness that leads to salvation: 'Or do you think lightly of the riches of his kindness and tolerance and patience, not knowing that the kindness of God leads you to repentance?' (NASV). Here in Romans 10:12, those who call upon Jesus, receive from him the benefits of his grace - the gift of eternal salvation. It is

5.To them belong the patriarchs, and from their race, according to the flesh, is the Christ, who is God over all, blessed forever. Amen' [italics added] (ó Xpıбtò cò katà

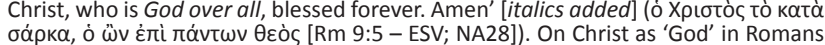

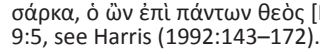


noteworthy that Paul refers to Jesus as the source of riches, and it is the Lord Jesus himself who bestows salvation on those who call on him. Jesus as Lord performs the role of God in dispensing salvation on those who call on him. It is from his abundant resources consequent to his death, resurrection and exaltation that Jesus can satisfy the request for salvation.

In anticipation of the climax of the rhetorical argument in Romans 10:13, Paul makes use of the significant verb from

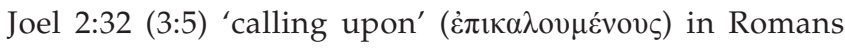
$10: 12 b$ ('bestowing his riches on all who call on him'

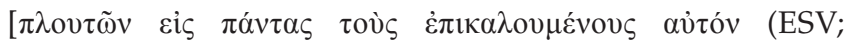
NA28)]). Anyone familiar with the Old Testament would almost certainly pick up on the allusion to the repeated phrase 'call on the name of the Lord' used throughout the Old Testament and most significantly in Joel 2:32 (3:5): 'everyone who calls on the name of the Lord will be saved'. This reference to Joel 2:32 (3:5) prepares the reader for the final explanatory $\gamma \alpha \dot{\alpha} \rho$ that introduces the direct quote from Joel. This verbal link makes a connection between Romans 10:12 and 13, and only serves to strengthen the unity of this passage.

The final statement in Romans 10:13 brings Paul's argument about the righteousness that comes by faith in Christ Jesus to a proper culmination. The final quotation from Joel 2:32 (3:5), prefaced with the fifth $\gamma \alpha \dot{\rho}$ in the series, brings the argument to its scriptural centre: 'For "everyone who calls on the name of the Lord will be saved"' ( $\pi \tilde{\alpha} \varsigma \gamma$ $\alpha \hat{\rho}$

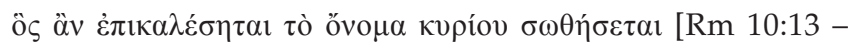
ESV; NA28]). The exegesis above makes it possible to answer the initial question: Who is the referent of the word 'Lord' in Romans 10:13, and what are the Christological implications of this assignment? The Joel quotation in Romans 10:13 contains various elements that weave it into the fabric of the preceding context. Romans 10:13 summarises the argument from verses 9-12 and answers the question of how Jews and Gentiles can be saved. The theme of salvation runs throughout the letter to the Romans and very specifically through Romans 10. Paul mentions salvation in Romans 10:1 ( $\sigma \omega \tau \eta \rho i \alpha v)$ with explicit mention also in verses 9-10 ( $\sigma \omega \theta \eta \dot{\sigma \eta \eta, ~} \sigma \omega \tau \eta \rho i ́ \alpha v)$ and finally

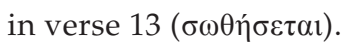

The research above shows that Paul interprets Isaiah 28:16 christologically and uses the shame motif to contrast the riches of salvation. Paul emphasises the universal aspect of the salvation available through Christ with the repeated use of $\pi \tilde{\alpha} \varsigma$. Paul started in Romans 1:16 ( $\pi \alpha v \tau i$ ) with an inclusive statement about salvation; he repeats it in 10:4 ( $\pi \alpha v \tau i)$, and continues this broad scope of salvation with the same word in verses 11 ( $\pi \tilde{\alpha} \varsigma), 12$ ( $\pi \alpha \dot{v} \tau \omega v, \pi \alpha \dot{v} \tau \alpha \varsigma)$ and 13 ( $\pi \tilde{\alpha} \varsigma)$. The addition of $\pi \tilde{\alpha} \varsigma$ in the Isaiah 28:16 quote in Romans 10:11 prepared the way for the universal scope of the scriptural support of Joel 2:32 (3:5).

\section{Jesus Christ and the Divine Name}

Perhaps the most shocking conclusion that Paul draws, is the identification of Jesus with the Divine Name of YHWH through the kúpios predicate. ${ }^{6}$ This conclusion is not premature, but is the result of following the sequence of the

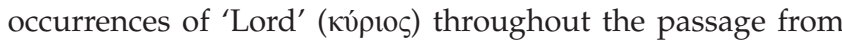

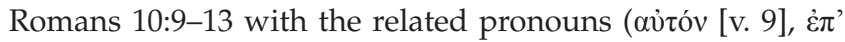

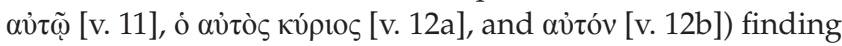
an antecedent in the person of Jesus. There is a line of thought that runs straight from the acclamation 'Jesus is Lord' (Rm 10:9) to the final 'Lord' of Joel 2:32 (3:5) through a sequence of

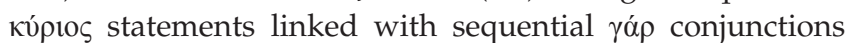
and related third person pronouns.

If there is any doubt that the kvpíov of Romans 10:13 finds its referent in the Jesus of the immediate context, the following verses (14ff.) further help to dispel confusion. Paul poses a series of questions that points back to the preceding text:

How then will they call on him in whom they have not believed

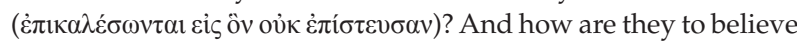
in him of whom they have never heard? (Rm 10:14 - ESV; NA28)

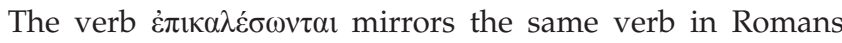
10:13, and غं $\pi i \sigma \tau \varepsilon v \sigma \alpha v$ joins the passage with the dialogue about belief in verse $9 \mathrm{ff}$. The relative pronoun ôv can only refer back to Romans 10:13 and its referent, Jesus, the Lord. In Romans 10:18, Paul answers the question about Israel not hearing: 'But I ask, have they not heard? Indeed they have, for "Their voice has gone out to all the earth, and their words to the ends of the world"' (ESV). What is the message that has

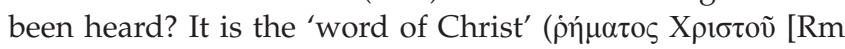
10:17 - NA28]). This leaves little doubt that the message about Christ had been preached, and the Jews (and Gentiles) have had ample opportunity to receive the message.

In the end, it is Paul's own argument in Romans 9:30ff that leads to the conclusion that the referent of 'Lord' in 10:13 is Jesus. This assignment carries great Christological weight. Paul finds a climax for his argument about the salvation of Jews and Gentiles in a passage that, in Hebrew, contains the Tetragrammaton and through the kv́pios predicate associates the ineffable Name with Jesus.

To suggest as Howard (1977) does that the Tetragrammaton likely stood in Paul's quotation of Joel 2:32 (3:5) and that the substitution of kúpros through scribal corruption points away from the author's original intent is without credible support. Romans 10:13 with all of its elements fits the context, and to 'return' to the Tetragrammaton has no manuscript support;

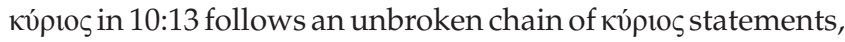
related pronouns and sequential conjunctions back to the initial confession: 'Jesus is Lord' (10:9). The text that has been received in the manuscripts of Romans 10:13 is undoubtedly from the pen of Paul and represents the intention of the author to associate Jesus Christ with the name of YHWH.

6.To the Hellenistic Jew, the significance of Paul's use of the familiar Old Testament phrase 'callon the name of the Lord', with kúploc as the qere for the Tetragrammaton, phrase callon the 12.1104-9]). Mor (se Origen, Selecta in Psalmos 2.2 [Patrologia Graeca (PG) 12.1104B4-9]). Moreover, the placement of this well-known passage in a section (Rm 9-11) dealing with Israel and salvation would only accentuate the Divine Name connection. 


\section{Christological conclusions}

Captured in Romans 10:13 is the climax of Paul's elevated Christology. In this verse comes the intersection of Old and New Testaments in the invocation of the Divine кúplos resulting in salvation for all. Jesus is the centre of saving faith; he is the 'stumbling stone' to the Jews, a role that YHWH has played in the history of Israel. Jesus is 'Lord' and this confession is essential in the story of salvation, forming a vital link with his resurrection. From his position of glory, Jesus unites Jew and Gentile as the 'Lord of all' who delivers from eschatological shame and bestows the riches of salvation on whoever calls to/on him. It is noteworthy that Jesus himself is called on for salvation, and the use of pronouns makes it clear that he generously gives the gift of salvation from his supply. To invoke the name of the Lord is to invoke the name of $\mathrm{YHWH}$, and only Jesus rightly assumes this role. Paul may not have used the language of the propositional theologian in claiming 'Jesus is $\mathrm{YHWH}^{\prime}$, but this conclusion is accomplished in his reasoning: 'His theological medium is instead that of overlap and resonance, such that he creates the overlapping conceptual space wherein this resonating identification occurs' (Rowe 2000:160). The name of Jesus, the Lord, is bound up with the name of YHWH through the kúpios predicate, and salvation can truly be found in no other. Howard (1977) fails to see how pivotal the YHWH quotation from Joel 2:32 (3:5) is in early Christian belief and practice. The high honours, which Jesus Christ receives as a result of kúpı๖ Christology, are therefore early, deliberate and well-established in the 1stcentury church.

\section{Romans 10:13 in Divine Name Bibles}

I have chosen to examine two Divine Name Bibles that claim to restore the Tetragrammaton to the New Testament text of Romans 10:13: The New World Translation of the Holy Scriptures (NWT) and The Scriptures (TS). There are a number of other similar translations that supply the Tetragrammaton in anglicised or Hebrew characters, and the conclusions reached in this article are broadly applicable to all. The aim of both translations is to restore to the New Testament text what was intended, but lost by the carelessness of later copyists. For the translators of the NWT, Howard's theory forms partial proof that Paul in Romans 10:13 would have used the Tetragrammaton in the quotation from Joel. The NWT translators argue that the Tetragrammaton, whether in Hebrew characters or Greek transliteration, was used by Paul in the otherwise Greek epistle (NWT, Appendix A5; NWT Greek Interlinear, Appendices 1A and 1B). The translators of TS argue that the New Testament 'originals were inspired in a Semitic language and not in Greek, as is commonly supposed' (TS, p. xviii). The result is the same: the Tetragrammaton in Hebrew or Greek characters is original to the New Testament and here specifically in Paul's Epistle to the Romans. The text of Romans 10:13 in the NWT and TS read as follows:
'For "everyone who calls on the name of Jehovah will be saved"' (NWT).

'For "everyone who calls on the Name of יהוה shall be saved"' (TS).

The only real difference between the two translations involves the language in which the Tetragrammaton is rendered.

In both cases, the reader is alerted to the referenced text in its 'original' form, and the significance of the Old Testament citation is brought to the foreground. What is less clear is the import to Paul's argument and the final form of the text as we have received it.

In the NWT, the referent to the argument changes from Romans $10: 9-10$ to $10: 11-13$. The flow of the argument is interrupted with a paragraph break beginning at Romans 10:11. The result is that Jehovah in distinction to Jesus is the referent of the paragraph in Romans 10:11ff. The difficulty is in the Greek text. The series of five connected statements each introduced with an explanatory ( $\gamma \alpha \dot{\rho} \rho)$ is interrupted with the paragraph break:

for ( $\gamma \alpha \dot{\alpha} \rho)$ in the heart it is believed ...

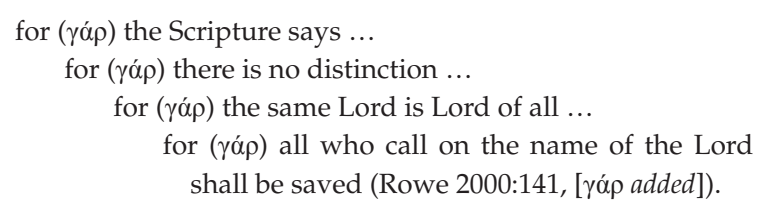

Futhermore, the sequence of occurrences of 'Lord' (кúpıss) and related pronouns which in the Greek find their antecedent in Jesus ( $\mathrm{Rm} \mathrm{10:9)}$ is also severed:

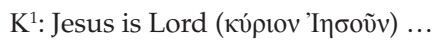

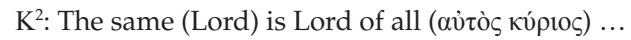
$\mathrm{K}^{3}$ : Everyone who calls on the name of the Lord (кирíov) will be saved.

In the Greek text, there is a line of thought that runs straight from the acclamation 'Jesus is Lord' (Rm 10:9) to the final 'Lord' of Joel 2:32 (3:5) through a sequence of кúpıoৎ statements linked with sequential ró $\rho$ conjunctions and related third person

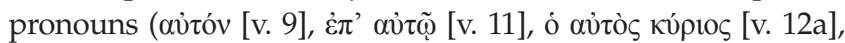
and av่tóv [v. 12b]). This sequence is violated with the NWT paragraph break at Romans 10:11. If we combine the collective documentary evidence of the extant manuscript corpus with the structural connections in this passage, the evidence is overwhelming that Paul intended to use the kúpros predicate in reference to Jesus Christ in Romans 10:13. To break the connection between Romans 10:9-10 from what follows, finds little support in the context and unnecessarily diverts the flow of Paul's continuing argument.

The NWT Greek Interlinear adds a footnote to support the decision to use 'Jehovah' in Romans 10:13. The footnote cites 'J $7,8,10,13-18,22-24$ ' in support of the rendering 'Jehovah' and $\mathrm{x} \mathrm{AB}$ 
TABLE 2: J Versions (NWT).

\begin{tabular}{llll}
\hline J Version & Author & Language & Publishing year \\
\hline J7 & Hutter & Hebrew & $1599-1600$ \\
J8 & Robertson & Hebrew & 1661 \\
J10 & Caddick & Hebrew & $1798-1805$ \\
J13 & McCaul, Alexander, Reichardt, Hoga & Hebrew & 1838 \\
J14 & Reichardt & Hebrew & 1846 \\
J15 & Biesenthal & Hebrew & $1851-1867$ \\
J16 & Reichardt, Biesenthal & Hebrew & 1866 \\
J17 & Delitzsch & Hebrew & $1877-1892$ \\
J18 & Salkinson, Ginsburg & Hebrew & 1886 \\
J22 & United Bible Societies & Hebrew & 1976 \\
J23 & Bauchet, Kinneret (Arteaga) & Hebrew & 1975 \\
J24 & Heinfetter & English & 1863 \\
\hline & & &
\end{tabular}

in support of 'Lord'. The series of 'J' versions are mostly modern Hebrew versions of the New Testament or some part thereof. Table 2 indicates the publishing date of each of the Hebrew (one English) 'J' versions (see Appendix 1 for full references). These J versions appear in the first position in the footnote followed by the three early codices ( $\mathrm{NAB}$ ) in support of 'Lord'.

For the untrained, the presence of three witnesses to the word 'Lord' and 12 to 'Jehovah' appears decisive. However, some method of weighing is in order. The J versions are all very late translations of the Greek New Testament or a translation language from Greek (e.g. Latin, Syriac, etc.). All are directly or indirectly dependent on the Greek text. There are no extant Greek New Testament manuscripts that contain the Tetragrammaton in Hebrew or Greek characters, and the multiplication of late Hebrew versions carries little weight. The Greek corpus of New Testament manuscripts and all early versions fail to yield an original New Testament Tetragrammaton, and the J versions offer little extra. Elsewhere, Howard (1986a; 1986b; 1986c; 1987; 1988a; 1988b; 1989; 1992a; 1992b; 1994; 1995; 1998; 1999) argues that the Tetragrammaton is found in an ancient Hebrew Gospel of Matthew preserved in the polemical work Even Bohan (אבן בוחן [The Touchstone]) written by Shem-Tob ben-Isaac ben-Shaprut, a Castilian Jew of the 14th century, but the evidence from Shem-Tob is likely late medieval (see Petersen 1989; 1998a; 1998b; Span 2018) and falls into the same category as the J versions above.

What we have is the interpretive decision to substitute the Tetragrammaton where the translator deems the underlying Old Testament quotation or allusion to contain the Divine Name or where the Tetragrammaton is contextually supported. It is this exegetical decision to replace the New Testament quotation or allusion from the Old Testament with the wording of the Hebrew quotation that is potentially problematic. There were reasons that the New Testament author chose the wording he did, and the Greek preserves the author's intention. To revert to the Hebrew wording in some places, obscures or redirects the meaning of the New Testament author's intended meaning.

In Romans 10:13, Paul is certainly applying the Tetragrammaton through the kúpıs predicate to Jesus in the interlinked YHWH quotation, but to suggest to the English reader that the Tetragrammaton is what Paul originally penned, is unfounded. The NWT changes the referent from Jesus to Jehovah with the paragraph break in Romans 10:11 and the reference to Jehovah in verse 13. The footnote supporting the 'Jehovah' translation is confusing, since the J versions are of little or no text-critical value.

I suggest that, in the next edition of the NWT, the editors remove the paragraph break at Romans 10:11. In both the NWT and TS, the danger is that the reader will be diverted from what is clear in the Greek. Romans 10:13 forms a climax to the previous verses, especially Romans 10:9ff. The 'restoration' of the Tetragrammaton leads away from the author's closely woven argument flowing into the Joel quotation. I advocate retaining the English word Lord as the preferred translation.

In the New Living Translation, the translators have used a helpful convention to show where there is an underlying Tetragrammaton in an Old Testament quotation cited in the New Testament. In Romans 10:13, кúpıos is rendered with the English word LORD all in small capitals. This preserves in English the connected word Lord with an indicator (capitals) that the Hebrew Vorlage contains the Tetragrammaton.

\section{Conclusion}

An original Tetragrammaton lacks documentary and contextual support in Romans 10:13. However, the application of a Divine Name passage to Jesus through the кúpıs predicate has great significance. The high honours ascribed to Jesus were not the product of later scribal corruption, but form an integral part of Paul's argument. Jesus is 'Lord' in the highest sense possible, and his connection to the Divine Name in Romans 10:13 is unmistakable. Jesus offers eternal salvation to all who call upon his name, a prerogative of $\mathrm{YHWH}$ alone, yet applied without reservation to the incarnate Lord.

\section{Acknowledgements Competing interests}

The authors have declared that no competing interests exist.

\section{Authors' contributions}

A.T.S wrote the article; S.T.R and F.J.v.R served in an editorial capacity.

\section{Ethical consideration}

This article followed all ethical standards for carrying out research without direct contact with human or animal subjects.

\section{Funding information}

This research received no specific grant from any funding agency in the public, commercial or not-for-profit sectors. 


\section{Data availability statement}

Data sharing is not applicable to this article as no new data were created or analysed in this study.

\section{Disclaimer}

The views and opinions expressed in this article are those of the authors and do not necessarily reflect the official policy or position of any affiliated agency of the authors.

\section{References}

Bauer, W., Danker, F.W., Arndt, W.F., \& Gingrich, F.W., 2000, A Greek-English lexicon of the New Testament and other early Christian literature, 3rd edn., University of Chicago, Chicago. [BDAG].

Blass, F., \& Debrunner, A., (eds.), 1961, A Greek grammar of the New Testament and other early Christian literature, transl. and rev. R.W. Funk, University of Chicago, Chicago, IL. [BDF].

Capes, D.B., 1994, 'YHWH and his Messiah: Pauline exegesis and the Divine Christ', Horizons in Biblical Theology 16(2), 121-143. https://doi.org/10.1163/ 187122094X00079

Cranfield, C.E.B., 1979, A critical and exegetical commentary on the Epistle to the Romans, 2 vols., International Critical Commentary, T\&T Clark, London.

Dunn, J.D.G., 1988, Romans 9-16, Word, Dallas, TX. (Word Biblical Commentary, 38B).

Freedman, D.N., Herion, G.A., Graf, D.F., Pleins, J.D., \& Beck, A.B., (eds.), 1992, The Anchor Bible Dictionary, 6 vols, Doubleday, New York, NY. [ABD]

Harris, M.J., 1992, Jesus as God: The New Testament use of Theos in reference to Jesus, Baker, Grand Rapids, MI.

Howard, G., 1977, 'The Tetragram and the New Testament', Journal of Biblical Literature 96(1), 63-83. https://doi.org/10.2307/3265328

Howard, G., 1986a, 'Shem-Tob's Hebrew Matthew', Proceedings of the 9th world congress of Jewish studies, World Union of Jewish Studies, Jerusalem, Aug 1985, pp. 223-230.

Howard, G., 1986b, 'The textual nature of an old Hebrew version of Matthew', Journa of Biblical Literature 105(1), 49-63. https://doi.org/10.2307/3261110

Howard, G., 1986c, 'Was the Gospel of Matthew originally written in Hebrew?' Bible Review 2(4), 15-25.

Howard, G., 1987, The Gospel of Matthew according to a primitive Hebrew text, Mercer University, Macon, GA.

Howard, G., 1988a, 'A note on the short ending of Matthew', Harvard Theological Review 81(1), 117-120. https://doi.org/10.1017/S0017816000009986
Howard, G., 1988b, 'A primitive Hebrew Gospel of Matthew and the Tol'doth Yeshu', New Testament Studies 34(1), 60-70. https://doi.org/10.1017/S0028688500022207

Howard, G., 1989, 'The textual nature of Shem-Tob's Hebrew Matthew', Journal of Biblical Literature 108(2), 239-257. https://doi.org/10.2307/3267296

Howard, G., 1992a, 'A note on codex Sinaiticus and Shem-Tob's Hebrew Matthew', Novum Testamentum 34(1), 46-47. https://doi.org/10.1163/156853692X00159

Howard, G., 1992b, 'A note on Shem-Tob's Hebrew Matthew and the Gospel of John' Journal for the Study of the New Testament 47, 117-126. https://doi.org/10.1177/ 0142064 X9201504707

Howard, G., 1992c, 'Tetragrammaton in the New Testament', in D.N. Freedman, G.A. Herion, D.F. Graf, J.D. Pleins, A.B. Beck (eds.), The Anchor Bible Dictionary, vol. 6 , pp. 392-393, Doubleday, New York, NY.

Howard, G., 1994, 'The Pseudo-Clementine writings and Shem-Tob's Hebrew Matthew', New Testament Studies 40(4), 622-628. https://doi.org/10.1017/ S002868850002405X

Howard, G., 1995, Hebrew Gospel of Matthew, Mercer University, Macon, GA.

Howard, G., 1998, 'Shem-Tob's Hebrew Matthew and early Jewish Christianity', Journal for the Study of the New Testament 70, 3-20. https://doi.org/10.1177/ 0142064 X9802007001

Howard, G., 1999, 'A response to William L. Petersen's review of Hebrew Gospel of Matthew', Textual Criticism 4, viewed 16 February 2017, from http://rosetta. reltech.org/TC/v04/Howard1999.html.

Hurtado, L.W., 2003, Lord Jesus Christ: Devotion to Jesus in earliest Christianity, William B. Eerdmans, Grand Rapids, MI.

JW.ORG, n.d., C4: Translations and Reference Works Supporting the Use of the Divine Name in the "New Testament", viewed n.d., from https://wol.jw.org/en/wol/d/ $\mathrm{r} 1 / \mathrm{lp}-\mathrm{e} / 1001070244 \mathrm{~m}=2$

Moo, D.J., 1996, The Epistle to the Romans, William B. Eerdmans, Grand Rapids, MI. (New International Commentary on the New Testament).

Petersen, W.L., 1989, 'The Gospel of Matthew according to a primitive Hebrew text: A review', Journal of Biblical Literature 108(4), 722-726. https://doi.org/ $10.2307 / 3267207$

Petersen, W.L., 1998a, 'Some observations on a recent edition of and introduction to Shem-Tob's "Hebrew Matthew"', Textual Criticism 3, viewed 16 February 2017, from http://rosetta.reltech.org/TC/vol03/Petersen1998a.html.

Petersen, W.L., 1998b, 'The Vorlage of Shem-Tob's “Hebrew Matthew"', New Testament Studies 44, 490-512. https://doi.org/10.1017/S0028688500016696

Rowe, C.K., 2000, 'Romans 10:13: What is the name of the Lord?', Horizons in Biblical Theology 22, 135-173. https://doi.org/10.1163/187122000X00081

Span, A.T., 2018, 'The Divine Name in the New Testament: Tetragrammaton or surrogate?', PhD thesis, North-West University.

Strazicich, J., 2007, Joel's use of Scripture and the Scripture's use of Joel: Appropriation and resignification in Second Temple Judaism and early Christianity, E.J. Brill, Leiden. (Biblical Interpretation Series, 82).

Trobisch, D., 2000, The first edition of the New Testament, Oxford University, New York, NY.

Wallace, D.B., 1996, Greek grammar beyond the basics: An exegetical syntax of the New Testament, Zondervan, Grand Rapids, MI. 


\section{Appendix 1}

The following are taken from the textual symbols listing in the New World Translation (NWT) Greek Interlinear (pp. 13-14) and collated against the fuller references in the NWT Study Edition, 'C4: Translations and Reference Works Supporting the Use of the Divine Name in the "New Testament"' (JW.ORG, n.d.). $\mathrm{J}^{13}$ and $\mathrm{J}^{14}$ have been retained according to the listing in the NWT Greek Interlinear; the new assignments for $\mathrm{J}^{13}$ and $\mathrm{J}^{14}$ in the NWT Study Edition are appended to the end of Table 1-A1 for reference.

\section{TABLE 1-A1: J Versions}

J Version Listing

$\mathrm{J}^{7}$ : Novum Testamentum Dñi: Nrì: lesu Christi, Syriacè, Ebraicè, Græcè, Latinè, Germanicè, Bohemicè, Italicè, Hispanicè, Gallicè, Anglicè, Danicè, Polonicè (New Testament in 12 languages, including Hebrew), by Elias Hutter, Nuremberg, 1599-1600. This edition is often referred to as the Nuremberg Polyglot New Testament.

J8: תורת יהוה חדשה, Lex Dei summi nova; Atque hæc est, Novum Domini nostri Jesu Christi Testamentum Sacro-Sanctum (New Testament, in Hebrew), by William Robertson, London, 1661.

$\mathrm{J}^{10}$ : The New Testament ..., in Hebrew and English, in Three Volumes, containing the Gospel of Matthew to First Corinthians, by Richard Caddick, London, $1798-1805$.

J13: ספר ברית חדשה על פי המשיח (New Testament, in Hebrew), by Alexander McCaul, Michael Solomon Alexander, Johann Christian Reichardt, and Stanislaus Hoga, London, 1838.

J14: ספר ברית חדשה על פי המשיח (New Testament, in Hebrew), by Johann Christian Reichardt, London, 1846.

J15: ספר בשורה טובה על פי המבשר לוקס (Gospel of Luke, in Hebrew), by Johann Heinrich Raphael Biesenthal, Berlin, 1851. ספר פעלי השליחים (Acts of Apostles, in Hebrew), by Johann Heinrich Raphael Biesenthal, Berlin, 1867.

אגרת אל הרומים (Paul's Letter to the Romans, in Hebrew), by Johann Heinrich Raphael Biesenthal, Berlin, 1855.

אגרת אל העברים הרומים (Paul's Letter to the Hebrews, in Hebrew), by Johann Heinrich Raphael Biesenthal, Berlin, 1857.

J16: הברית החדשה על פי המשיח עם נקודות וטעמים (New Testament, in Hebrew), revised by Johann Christian Reichardt and Johann Heinrich Raphael Biesenthal, London, 1866.

J17: ספרי הברית החדשה (New Testament, in Hebrew), by Franz Delitzsch, Leipzig, 1877-1892.

J18: הברית החדשה (New Testament, in Hebrew), by Isaac Salkinson and Christian D. Ginsburg, Vienna, Austria, 1886.

J22: ספרי הברית החדשה (New Testament, in Hebrew), by United Bible Societies, Jerusalem, 1976.

J3: הברית החדשה (New Testament, in Hebrew), by Yohanan Bauchet and David Kinneret (Arteaga), Rome, 1975.

J24: A Literal Translation of the New Testament ... From the Text of the Vatican Manuscript, by Herman Heinfetter (pseudonym for Frederick Parker), Sixth Edition, London, 1863.

J13: הברית החדשה (New Testament, The Gospels in Hebrew), by Thomas Yeates, London, 1805. As reproduced by Jean Carmignac in Traductions hebraïques des Evangiles, Vols. 2-3, Turnhout, Belgium, 1982; from the manuscript Add MS 11659 in the British Library, London.

J14: ספר ברית חדשה על פי המשיח (New Testament, in Hebrew), by Alexander McCaul, Michael Solomon Alexander, Johann Christian Reichardt, and Stanislaus Hoga, London, 1838.

$\dagger$, New World Translation Study Edition. 